\title{
Political Development as a Factor for Election of Young Legislative Candidates in the 2019 General Election in Jambi Province
}

\author{
Dori Efendi ${ }^{1}$, Nopyandri ${ }^{2}$ \\ \{doriefendi@yahoo.com ${ }^{1}$ \} \\ Universitas Jambi, Indonesia ${ }^{1}$ \\ Universitas Jambi, Indonesia ${ }^{2}$
}

\begin{abstract}
In the democracy era every candidate has the oportunity to be elected in the General Election constestation. The electability of this young legislative candidate can be accessed through political development. This is because political development in Indonesia goes to the stage of "civil administration", namely political progress and order. This research discusses how to develop politics as a major factor in the election of young legislative candidates in the 2019 elections and how to get them elected? This article answers these questions. Presupposition that is built to answer the above questions that is the strategy of young legislative candidates in building image, popularity and good personal electability will attract people to vote for them and succeed in attracting the sympathy of novice voters to vote for them. Their election in this election is also a representation of increasing political education, maturity of voters and more mature democracy.
\end{abstract}

Keywords: Political Development, Young Legislative Candidates, 2019 Election.

\section{Introduction}

After the new order, Indonesia politics was marked by many changes. One of them was the simultaneous general election which covered the election of the President, the Regional Representative Board (Dewan Perwakilan Daerah (DPD), the House of People's Representative (Dewan Perwakilan Rakyat (DPR RI)), the Provincial People's Representative Board and the City Regional People's Representative Board. Hatherell [1] stated that Indonesian politics increasingly prioritizes people's electabilitys that are proven to work namely "The Indonesian political reform adopting a new approach that focuses on the cultural and performance aspects of representation and draws on a substantive evidence base of representative claims." It means that this people's electability is proven to work for the progress and welfare of its people such as Tri Rismaharani (Surabaya City), Ridwan Kamil (Bandung City), Basuki Tjahaya Purnama (DKI Jakarta) and Nurdin Abdullah (Bantaeng Regency).

In this connection, scientific studies on the electability of young legislative candidates are still relatively limited. At least there were some relevant studies used in this research. First, Syarifuddin Jurdi's book. Jurdi [2] described the political participation of young people in the Indonesian political stage as an entry point to understand the political existence of young people. In addition, this book also criticizes the weakness of young people's participation in Indonesian politics. Nevertheless, through this book, it can be concluded that the leadership of young people 
has re-emerged in the 2019 elections with the marked number of candidates running for election. Even Sandiaga Uno's vice-presidential candidates are regarded to represent young people (millennial).

Previously, there was the book Laode Ida [3] that discussed the involvement of young Nadhlatul Ulama politicians in parliament. This book explains the strength of the NU group which was considered conservative by other groups in the 2004 election turned into a new progressive group and secularism. This happened because the NU youths were critical cadres in the parliament and the legacy of President Gus Dur who was humanist while leading Indonesia in 1999-2001.

A recent study was carried out by Aspinall \& Barenschot [4] who discussed democratic freedom and elections that led to clientelism in Indonesian politics. Aspinall \& Barenschot [4] strongly criticized democratic freedom but instead praised the courage of young legislative candidates who were willing to get involved in politics. It can be said that the anti-political attitude of young people in the previous election changed to be positive and competitive in the 2014-2019 elections. This is because young people have a high degree of electability because of the millennial phenomenon with their voting rights reaching 50\% in the 2019 elections.

Tabel 1. Number of Parties Who Carry Young Legislative Candidates in 2014-2019 Elections

\begin{tabular}{ccc}
\hline Year & Number of parties & Number of candidates \\
\hline 2014 & 12 & 414 \\
2019 & 16 & 878 \\
\hline
\end{tabular}

The table above shows that in 2014 there were 12 parties nominating 414 young legislative candidates to take part in the competition to win the seat of the legislative assembly. Whereas in 2019 the number of legislative candidate involvement has increased by $100 \%$ to as many as 878 candidates. Burhanuddin Muhtadi [5] stated the emergence of young legislative candidates in the politics of 2014-2019 because the votes of young voters (millennial generation) reached 80-100 million under the age of 40 years. This means that nearly $50 \%$ of the votes of the younger generation have the right to vote to elect their representatives in parliament.

Referring to studies outside Indonesia, studies on the electability of young people in politics have long been developing. However, the latest study is about Student Moves that took place in Hong Kong, also known as the Umbrella Revolution, which was coined by Joshua Wong in 2014. This movement demands separation from China. According to Ngok Ma \& Cheng [6], the attitude of optimism of young people in the era of globalization and advances in information technology has resulted in political changes. This attitude is what made the civil society in the 2016 elections in Hong Kong chose young people as their representatives in parliament. There is also a paper written by Welsh [7] which explains about democratic elections and their impact on the election of young people in the election of the House of Representatives. Welsh explained again that voter behavior in the Johor-P146 province of Muar was a rational society in making electabilitys. This is because they chose a young person whose background is achievers, Syed Saddiq Syed Abdul Rahman with a total of 22,341 thousand votes and defeated defense from the Datuk Seri Razali Ibrahim National Front which received 15,388 thousand votes.

The study of the election of young legislative candidates in Indonesia is increasingly interesting to be examined because of the phenomenon of political parties that are increasingly carrying young candidates such as Partai Soalidaritas Indonesia carrying 171 young legislativ 
candidates, Partai Garuda (84), Partai Persatuan Pembangunan (81), Partai Kebangkitan Bangsa (78), Partai Amanat Nasional (58), Gerindra dan Perindo (each carrying 56), NasDem (52), Golkar (45), Hanura (37), Partai Berkarya (35), PDI-P (34), PKS (31), Demokrat (24), Partai Bulan Bintang (21), dan PKPI (20) [8].

From the above background, this article aims to answer the question of what factors made people chose young legislative candidates in Jambi City? To answer these questions the author used the concept of Political Development as a knife of analysis.

\section{Methods}

This study used a qualitative research approach to measure the level of electability of young legislative candidates in the 2019 general election in the city of Jambi. Data collection techniques used in this study were literature study methods in the form of gathering references and secondary data. While the analysis of the data used was a qualitative analysis technique that was by using the steps of reduction analysis and analysis of data presentation.

\section{Findings and Discussion}

\subsection{The Concept of Political Development}

What is political development? Political development refers to the change from a bad problem to a better one. However, most political science scholars have different views about the forms of change in political development. Rustow [9] defines political development as: "(1) increasing national political unity plus, (2) broadening the base of political participation." increase political participation. National political unity refers to stable politics with political actors working together to develop the country. Political participation also refers to community involvement in political activities including in elections to elect and elect political leaders and parties. Rustow sees these two elements as the most important elements of political development that need to be realized in a country.

Why so? According to Riggs [10], this is because political development is a change from the form of society that has passive political participation to people who have active political participation. Communities who have active political participation have a positive impact on state politics. Thus, the active political participation of the community influences the planning of state policy. It also shows that the state gives good civil liberties. In summary, a passive society that does not participate in politics causes political development in the country to not occur and this gives the impression of political democracy in the country. Not much different from Rustow [9] and Ring [11], Coleman [12] also explains almost the same definition, namely:

Political development refers to those processes of differentiation of political structure and secularization of political culture which enhances the capability, the effectiveness and efficiency of performance-of a society's political system-the interactions characteristics of a traditional polity are predominantly ascriptive, particularistic and diffused, those of a modern polity are predominantly achievement oriented, universalistic and specific. Political development is viewed as the process of movement from the traditional pole to the modern pole of the continuum. 
Coleman regards that political development occurs when there is a change in political structure from the traditional political system to the modern political system for the creation and stability of the country's political democracy. Modern political structures have a better impact than traditional political structures that are seen as backward, not systematic and have many weaknesses. This is because for Coleman, the political structure is important because the development and progress of the country depends on a good and memorable political system.

\subsection{Factors of Young Legislative Candidates Election}

In the 2019 election, the young legislative candidate got a special place for voters. This is due to the hectic involvement of young legislative candidates in the 2019 elections. Likewise, with the millennial phenomenon which is a struggle for young legislative candidates to win votes. This is proven in the acquisition of votes, where young legislative candidates got the highest votes in each electoral district.

Tabel 2. The level of Electability of Young Legislative Candidates

\begin{tabular}{lcc}
\hline \multicolumn{1}{c}{ Name of Candidates } & Age & Poll \\
\hline Rocky Candra & 32 & 16.023 \\
\hline Ezzaty & 22 & 33.004 \\
\hline Juwanda & 36 & 13.860 \\
\hline
\end{tabular}

From the data above, three young legislative candidates got the most votes from their respective electoral districts. Referring to Governor Zumi Zola's "Uang Ketok Palu" which was a representation of young people, the Jambi community does not show an anti-political attitude towards young people. On the other hand, they will continue to give young people the confidence to lead Jambi in the next five years. The question is what are the factors of young legislative candidates' electability in the 2019 elections? There are at least three main factors. First, the background of young legislative candidates or personal branding. In the language of Huntington [13] there are two groups of people namely traditional society and modern society to see the mobilization and participation of people in politics. He stated that traditional society is a society that does not participate in politics, while modern society is also the opposite. Changes from traditional societies to modern societies participating in political activities are important to ensure that political development in the country takes effect. This is confirmed again by Rocky Candra:

... The constituents or time bases that choose me tend to be millennials or young people whose rational behavior is rational. They considered me to be their representation because of my simple family background. Not only that, they also judge from my seriousness during the campaign by going down to the community. But they also saw my vision and mission which prioritized young people's progress with the political jargon that I used \#pududaberakerakan

The choice of Rocky Candra is also closely related to his optimistic political campaign to advance the region. This is because during political campaigns, Rokcy Candra is known by his constituents to be young people who succeed from an economic standpoint. In the context of winning the hearts of voters, Rocky Candra is also known as an expert in winning votes. This is proven where he succeeded in defeating the popularity of Edi Purwanto, who was in the same 
electoral district with him and was also a legislative member and deputy governor candidate in 2015. Related to this, the number of votes won by Rocky Candra also led to the election of a second seat for the Gerindra party. This is because the vote counting system used in the 2019 elections is the sainte lague system. The election of Rocky Candra is also almost the same as what happened with Juwanda who won the candidacy in electoral area III Sarolangun-Merangin. Juwanda who has a young activist background is able to attract the sympathy of the people to vote for her. Likewise, Ezzaty whose background was the son of the Mayor of Sungai Penuh succeeded in capturing the hearts of voters to elect him as a representative of the electoral district IV Kerinci-Sungai Penuh.

Second, vision and mission. Roth [14] explains that there are three elements in the election of legislative candidates, namely: (i) due to personal perceptions and assessments of candidates; (ii) perception of political objectives; and (iii) identification and credibility of candidates. These three elements indicate the existence of voter confidence in the competence of young legislative candidates in the 2019 elections. Interview with Rocky Candra (2019) said:

... that my vision and mission in carrying "with young people ideas into change" is my optimistic attitude to advance the region. Not only that, I also have a team that is loyal in winning me, namely a mobile youth team, all of whom are young people like friends of Ikatan Mahasiswa Muhammadiyah (IMM), Himpunan Mahasiswa Islam (HMI), Tunas Indonesia Raya (TIDAR) and there are also friends Fof Gerindra Masa (GMD). ${ }^{1}$

Referring to the reality of Roth [14] the election of young candidates is a role model that is a role model and an example for young people who are successful in their careers be it economic, political and others. This is also the same as the vision of Juwanda who a young activist from Nahladtul Ulama is who became a role model for young voters from NU who succeeded in putting their cadres in parliament. No different from Ezzaty who a representation of young people is also, but it represents the female group. In accordance with what Huntington said in the development of political participation and mobilization is an important indicator in measuring the level of electability of legislative candidates. According to Huntington [15], mobilization and participation refer to changes in attitudes, values, and viewpoints of people rather than matters relating to the traditional world to the modern world. These changes are in the form of individual, group and community aspirations. Social mobilization occurs when it manifests literacy development, education, increased communication, exposure to mass media, and urbanization in the country. That is, young legislative candidates who were elected because they already have high social capital such as Rocky Candra are known to have economic power, Juwanda activist power and Ezzaty bureaucratic power.

Third, current trends. The election of this young legislative candidate is associated with an understanding of the existence of the millennial group phenomenon which has a vote of almost $50 \%$. This is also related to the change in voter behavior from traditional to modern, ie millennials get information faster from social media. Even in the 2019 election the Indonesian Millennial Movement was born supporting Prabowo-Sandi and the millennial group KitaSatu Jokowi-Maruf Amien supporters were a form of political change. According to Wasisto Raharjo Jati [16] the phenomenon of millennial causes a shift in procedural democracy to digital

\footnotetext{
${ }^{1}$ In this interview, Rocky Candra also explained the strength of young people is the real strength that I have because this team is very loyal and not money oriented. That is why the people of Jambi City chose me. Interview at his home in Jambi City, 5 July 2019.
} 
democracy. This is very beneficial for young legislative candidates because they are active in conducting political campaigns through the mass media.

In addition, millennial groups consider that the election is no longer meant as a succession of powers but a succession of interests. In accordance with political perception is an interest, the millennial generation thinks that posting and sharing gives a positive impact on political education compared to political education carried out by political parties. Therefore, it can be said that the preference for choosing is no longer constructed but labeled. This is one indicator of the election of young legislative candidates in the 2019 elections in gaining the highest votes from each electoral district.

\section{Conclusions}

The election of young legislative candidates in the 2019 elections in Jambi province showed the occurrence of political development and changes in voter behavior. This election was followed by an increase in the number of millennial votes reaching $50 \%$ in the 2019 elections. This election was also caused by two main factors. First, the background of candidates judged by millennial voters is a role model that is their role model and their representative in politics. Second, vision and mission that were easily accessed by millennial voters through social media. And third, the current trend is internet democracy which makes it easy for millennial groups to determine attitudes in choosing. This is what is said as political polity in which political order occurs. Political participation no longer has to be demonstrated through street support. Millennial groups share and post on social media to provide support to the candidates they support. On this basis, political education and political participation of millennial groups succeeded in placing young legislative candidates in the 2019 elections that were a representation of themselves.

\section{References}

[1] M. Hatherell, Political Representation in Indonesia: The Emergence of the Innovative Technocrats. Routledge, 2019.

[2] S. Jurdi, Kekuatan-Kekuatan Poitik Indonesia. Kencana, 2016.

[3] L. Ida, NU muda: kaum progresif dan sekularisme baru. Erlangga, 2004.

[4] E. Aspinall and W. Berenschot, Democracy for Sale: Pemilihan Umum, Klientelisme, dan Negara di Indonesia. Yayasan Pustaka Obor Indonesia, 2019.

[5] B. Muhtadi, "Populisme Politik Identitas \& Dinamika Elektoral: Mengurai Jalan Panjang Demokrasi Prosedural," Malang Instrans Publ., 2019.

[6] N. Ma and E. W. Cheng, The Umbrella Movement: Civil Resistance and Contentious Space in Hong Kong. Amsterdam University Press, 2019.

[7] B. Welsh, “'Saviour' Politics and Malaysia's 2018 Electoral Democratic Breakthrough: Rethinking Explanatory Narratives and Implications," J. Curr. Southeast Asian Aff., vol. 37, no. 3, pp. 85-108, 2018.

[8] M. Kresna, "Yang Muda yang Nyaleg: Berebut Suara Pemilih Milenial," tirto.id, 2019. .

[9] D. A. Rustow, A world of nations: Problems of political modernization. Washington: Brookings Institution, 1967.

[10] F. W. Riggs, "The theory of developing polities," World Polit., vol. 16, no. 1, pp. 147-172, 1963.

[11] A. A. Ring, The valuation of real estate. Prentice-Hall, 1970. 
[12] J. S. Coleman and J. S. Coleman, Nigeria: Background to nationalism. Univ of California Press, 1958.

[13] S. P. Huntington, "Political development and political decay," World Polit., vol. 17, no. 3, pp. 386-430, 1965.

[14] D. Roth, "Studi Pemilu Empiris: Sumber, Teori-teori, Instrumen dan Metode," Jakarta Für Die Freiheit, 2008.

[15] S. Huntington, "P.(1968)," Polit. order Chang. Soc., p. 45, 1968.

[16] W. R. Jati, "Peran milenial dalam demokrasi di tahun politik 2019," Di sampaikan dalam kuliah umum Univ. Bangka Belitung, 2019. 